\title{
Bilgiler Eğitimi Öğretmen Adaylarının Matematiğe İlişkin Bakış Açıları ${ }^{1}$
}

\author{
Meryem ÖZTURAN SAĞIRLI ${ }^{2}$ \\ Zeynep ÇAKMAK ${ }^{3}$ \\ Fatih BAŞ $^{4}$ \\ Muzaffer OKUR ${ }^{5} \quad$ Mehmet BEKDEMIR $^{6}$
}

Geliş Tarihi: 21.10.2013 Kabul Tarihi: 16.02.2015

\section{Öz}

$\mathrm{Bu}$ araştırmanın amacı; sosyal bilgiler öğretmen adaylarının; algıladıkları matematik başarıları, fobi ve kaygıları açısından matematiğe karşı tutumlarını ortaya koyabilmektir. Durum çalışması yönteminin temel alındığı araştırma; 2011-2012 öğretim yılı bahar döneminde İlköğretim Bölümü Sosyal Bilgiler Eğitimi Anabilim Dalı'nda öğrenim görmekte olan 30 dördüncü sınıf öğretmen adayı ile gerçekleştirilmiştir. Katılımcılardan 13'ü dördüncü sınıfta seçmeli olan matematik dersini almışken 17'si bu dersi almamıştır. Hazırlanan 5 soruluk görüşme formu yardımıyla veriler toplanmış ve içerik analizine tabi tutulmuştur. Araştırma sonucunda; dersi almayan gruptaki katılımcıların alan gruba kıyasla kendilerini matematikte daha başarısız olarak nitelendirdikleri ve bu durumu matematik öğretmenleri, atılamayan matematik temelleri, çalışmamaları, ilgi duymamaları gibi sebeplere bağladıkları görülmüştür. Matematik dersini alan grupta katılımcıların \%31'inin almayan grupta ise $\% 47$ 'sinin matematik fobisi olduğu ve bu durumun temel olarak bu dersteki başarısızlıklarından kaynaklandığı sonucuna ulaşılmıştır. Ayrıca dersi alan katılımcıların \%54'ünün almayanlarda ise \%82'sinin matematik kaygısına sahip oldukları belirlenmiştir. Sınav kaygısı, hiç öğrenememe, temel eksikliği, öğrenip unutma, her zaman gerekli olma, sürekli başarısız olma ve işlem korkusu söz konusu bu kaygının katılımcılar tarafından ifade edilen nedenleridir. Son olarak katılımcıların büyük çoğunluğunun matematik dersinde başarılı olmak istedikleri, dersi yararlı olarak nitelendirdikleri ve Sosyal Bilgiler Öğretmenliği Lisans Programı'nda yer alması gerektiğini düşündükleri görülmüştür.

Anahtar Kelimeler: Matematik algısı, sosyal bilgiler öğretmen adayları, tutum, kaygı

\footnotetext{
${ }^{1}$ Bu araştırmanın kısa bir özeti 27-30 Haziran 2012 tarihlerinde Niğde Üniversitesi’nde gerçekleştirilmiş olan X. Ulusal Fen ve Matematik Eğitimi Kongresi'nde sunulmuştur

${ }^{2}$ Yrd. Doç. Dr., Erzincan Üniversitesi Eğitim Fakültesi, msagirli@erzincan.edu.tr

${ }^{3}$ Arş. Gör., Erzincan Üniversitesi Eğitim Fakültesi, zcakmak@erzincan.edu.tr

${ }^{4}$ Yrd. Doç. Dr., Erzincan Üniversitesi Eğitim Fakültesi, fbas@erzincan.edu.tr

${ }^{5}$ Doç. Dr., Erzincan Üniversitesi Eğitim Fakültesi, mokur@erzincan.edu.tr

${ }^{6}$ Doç. Dr., Erzincan Üniversitesi Eğitim Fakültesi, mbekdemir@erzincan.edu.tr
} 


\title{
Pre-Service Social Science Teachers’ Perceptions on Mathematics
}

Submitted by 21.10.2013 Accepted by 16.02.2015

\begin{abstract}
The aim of this study is to determine pre-service social science teachers' attitudes towards mathematics from the viewpoints of perceived mathematics achievement, phobia and anxiety. The study adopting case study methodology was carried out with 30 senior students who were educated in the social sciences teaching department in the spring semester of the academic year 2011-2012. While 13 of the participants enrolled in the elective mathematics course, the rest 17 students did not take this course in their last year. The data were collected with a 5 question-interview form and analyzed with content analysis way. The findings showed that students who did not take mathematics course felt less successful in mathematics then the students who took the course. The students expressed this situation by relating it with their mathematics teachers, lacking the fundamentals of mathematics, not studying mathematics and not feeling interested in mathematics. \% 31 of the students taking mathematics course and $\% 47$ of the students not taking the course felt mathematics phobia and the main reason of it was students' failure in the course. In addition, \% 54 of the students taking mathematics course and \% 82 of the students not taking the course had mathematics anxiety. The main reasons of this anxiety stated by the participants were feeling exam anxiety, not learning, lacking knowledge, forgetting, not using mathematics too much, feeling constant failure and operation fear. Lastly, majority of the participants desired to be successful in mathematics, found mathematics course beneficial and thought that social sciences teaching department curricula ought to include mathematics course.
\end{abstract}

Key Words: Perception of mathematics, pre-service teachers of social sciences, attitude, anxiety 


\section{Giriş}

Matematik, y1llardır öğrencilerin süregelen en büyük problemi olmuştur ve olmaya da devam etmektedir (Başar, Ünal ve Yalçın, 2002). Kimi öğrenciler için bu ders; sıkıcı, sevilmeyen, korkulan (Yenilmez ve Duman, 2008; Şahan, 2006), ne işe yaradığı bilinmeyen veya mezun olabilmek için aşılması gereken bir engel olarak algılanmakta hatta günlük yaşamdan çok uzak, uğraşılamaz, ulaşılamaz, akıl-sırrın ermediği, sadece bilim adamlarının yaptığı uğraşılar olarak görülmektedir. Kimi öğrenciler için ise durum farklı olup onlar için matematik sadece okulda yer alan bir dersten öte hayatlarını kolaylaştıran zevkli bir uğraş alanı olarak algılanmaktadır. Ancak çoğu öğrencinin matematikle arası pek de iyi olmasa gerek ki (Kahramaner ve Kahramaner, 2002) matematik başarısını değerlendiren sınavlar genelde olumsuz sonuçlarla bizi uyarmaktadır.

Uluslararası Öğrenci Değerlendirme Programı (PISA) benzeri diğer ulusal ve uluslararası düzeyde yapılan sınavların sonuçları ve ilgili bilimsel araştırma sonuçları, Türk öğrencilerin matematik alanında genelde son sıralarda yer alarak diğer ülkelere göre başarısız olduklarını ortaya koymuştur (Berberoğlu, 2007). Ülkemizin matematik dersi açısından başarısız sayılabilecek noktada olması akademisyenleri bu sorunla ilgilenmeye itmiş ve öğrencilerdeki matematik başarısının düşüklüğünün nedenini inceleyen birçok çalışma yapılmıştır. Bu çalışmalarda matematik başarısızlığının nedenleri korku, tutum, ailesel ve çevresel etmenler gibi birçok faktörle ilişkili bulunmakla beraber söz konusu durumun önde gelen sebeplerinden biri olarak da öğrencilerin yaşadıkları matematik kaygısı gösterilmiştir (Berberoğlu, 2007; Bindak, 2005).

Matematik kaygısını, günlük ve akademik hayatta matematik problemlerinin çözümüne ve sayıların kullanımına engel olan kaygı ve gerginlik duyulan (Richardson ve Suinn, 1972) veya matematiksel düşünmede öğrencilerin öylece kalakalmalarına neden olan, performanslarını düşüren dolayısıyla da öğrenmelerini engelleyen mantık dışı korku hali (Miller ve Mitchell, 1994) olarak tanımlamak mümkündür. Matematik kaygısına sahip insanlar, matematiğe karşı derin bir nefret ve korku yaratan büyük sıkıntı anlarını uzun yıllar canlı bir şekilde hatırlamakta ve oluşturdukları olumsuz tutumlarını muhafaza etmektedirler (Miller ve Mitchell, 1994; Jackson ve Leffingwell, 1999). Bireylerde korkuyu yaratan tehlike açık ve nesnel olmasına karşın, kaygıyı yaratan tehlike gizli ve özneldir (Arıkan, 2004). Ayrıca kaygıyı yaratan bu gizli ve öznel tehlike çeşitli araştırmacılar tarafindan aydınlatılmaya çalışılmıştır. Bekdemir (2007) matematik kaygısını arttıran faktörlerin en önemlilerini; öğretmenin olumsuz tutum ve uygulamaları, zamanla sınırlandırılmış matematik 
sınavları, matematik derslerinde hata yapma korkuları, matematik öğretmenlerine anlaşılmayan yerlerin sorulamaması, grupla, somut materyal veya el becerileriyle çalışma fırsatının bulunmaması olarak sıralamıştır. Keçeci (2011) ise Byrd'den (1982) esinlenerek öğrencilerin matematik eğitimine ve başarısına dair duydukları korku ve kaygı ile ilgili yapılmış çalışmaları incelemiş olup, elde edilen sonuçların ışığında matematik kaygısının genel sebeplerini; alandan kaynaklanan, eğitim ve eğitmenden kaynaklanan ve öğrencinin kendisi ve çevresinden kaynaklanan genel sebepler olarak açıklamıştır.

Matematik öğretiminde yaşanan olumsuzluklar sonucunda, bu bilim dalının anlaşılmazlığının yarattığı kaygı, sonuçta, bu derse karşı olumsuz tutumun ilköğretimin ilk yıllarında gelişmesine neden olarak, öğrenme ya gecikmekte ya da istenilen düzeyde gerçekleşmemekte; ayrıca, birey matematiği, kendisinin yapabileceği bir iş olmadığını, zekâ ve kapasite olarak kendisini aştığını düşünmektedir (Sırmac1, 2007). Öğretimin ilk yıllarında yaşanan bu olumsuz tutum, çoğunlukla ortaöğretime hatta yükseköğretime sıçrayarak devam edebilmektedir. Dolayısıyla öğrencilerin matematik algısı zamanla değişebileceği gibi bazen de değişmeden yıllarca varlığını koruyarak yükseköğretim yıllarına kadar yansıyabilmektedir. Duatepe ve Çilesiz (1999) üniversitelerin birinci sınıflarında zorunlu olan matematik dersinde başarısız olan öğrencilerin çoğunun bu ders hakkında olumsuz düşüncelere sahip olduğunun gözlenmekte olduğunu bildirmektedir.

Matematik kaygısı yanında bireylerin belirli bir kişiyi, grubu, kurumu veya bir düşünceyi kabul ya da reddetme şeklinde gözlenen duyuşsal hazır oluş hali veya eğilimi (Özgüven, 1994) olarak tanımlanan tutum da matematik başarısını etkileyen etmenler arasındadır. Öğrencilerin matematik dersi ile ilgili duygularından ortaya çıkan matematiğe karşı tutumları, matematik eğitiminde oldukça önemli bir yere sahiptir (Aydın, 2011). Çünkü matematikteki başarı ile matematiğe yönelik tutum arasında karşılıklı bir ilişkinin varlığını söyleyen birçok çalışmaya (Duru 2002; Duru, Akgün ve Özdemir, 2005; Şahin, 2004; Frary ve Ling, 1983) rastlanmaktadır. Eğitim Fakültesi öğrencilerinin matematiğge ilişkin olumlu ya da olumsuz tutumların kaynağı sorgulandığında öğretmen odaklı korkular dikkati çekmektedir (Şahan, 2006). Bekdemir, Işık ve Çıkılı (2004) matematik kaygısıyla ilgili yapılan araştırmaları inceledikleri çalışmalarında; matematik kaygısını dolaylı veya dolaysız etkileyen nedenlerin başında öğretmen davranışlarının geldiğinin görüldüğünü ifade etmişlerdir.

Okulların amaçlarından bir tanesi de öğrencinin mesleki ilgi ve yeteneklerinin ortaya çıkmasını sağlamak olduğu göz önüne alındığında; öğretmenlerin bu amacı gerçekleştirmek için kendilerinde var olan kaygı, korku ve fobi durumlarını öğrencilerine yansıtmamaları ve 
objektif davranabilmeleri gerekmekte veya öğrencilerin matematik başarısını olumsuz yönde etkilememeleri açısından (Dursun ve Dede, 2004) bu durumdan bir an önce kurtulmaları gerekmektedir. Dolayısıyla öğrencilerde var olan matematik algısını öğrenebilmek bu açıdan önem arz etmektedir. Bu nedenle geleceğin öğretmeni olacak eğitim fakültelerinde öğrenim gören öğrencilerdeki matematik başarısızlığına neden olan korku ve kaygı gibi faktörlerin hangi düzeyde olursa olsun derinlemesine analiz edilerek anlaşılması ve aşılması gerekmektedir. Çünkü matematiğe yönelik inanışlar, davranışlar ve yeni deneyimler için bir süzgeç görevi görürler (Pajares, 1992). Zira kaygı nedeniyle, matematiğe karşı oluşturulan olumsuz tutumlar, özellikle öğrencilerde bulunan matematik yeteneklerin ortaya çıkışını da etkileyen önemli bir faktördür (Hannula, 2005). Öğrencilerin matematiği algılayışlarını doğru bir şekilde anlayıp analiz edebilirsek o ölçüde öğrencilerimize daha kaliteli eğitim fırsatları sunabiliriz. Bu bağlamda yapılan çalışmalar diğer bölümlere göre matematik başarısı nispeten daha düşük, genel olarak matematiği sevmeyen ya da matematik kaygısı taşıyan ve kendilerini sözelci olarak tanımlayan öğrencilerin içinde bulunduğu sosyal bilgiler öğretmen adaylarının matematik algılarının belirlenmesi hedeflenmiştir. Literatürde matematik başarısızlı̆̆ının ve matematiğe yönelik inançların nedenlerini inceleyen birçok araştırma bulunmakla (Başar ve diğ., 2002; Duru ve diğ., 2005; Dede ve Karakuş, 2012; Keçeci, 2011; Savaş, Taş ve Duru, 2010; Tunç ve Haser, 2012) beraber çalışmanın sözel bir alan olan sosyal bilgiler ana bilim dalı öğretmen adaylarıyla yapılması ve durumun nitel bir yöntemle ortaya çıkarılmaya çalışılmasının literatürdeki çalışmalar açısından farklı bir yön oluşturduğu düşünülmektedir.

$\mathrm{Bu}$ araştırmanın amacı dördüncü sınıf düzeyinde seçmeli olan matematik dersini alan ve almayan sosyal bilgiler öğretmen adaylarının; algıladıkları matematik başarıları, fobi ve kaygıları açısından matematiğe karşı tutumlarını ortaya koyabilmektir.

\section{Yöntem}

Araştırmada bir ya da daha fazla olayın, ortamın, programın, sosyal grubun ya da diğer birbirine bağlı sistemlerin derinlemesine incelenmesine imkân tanıyan (McMillan ve Schumacher, 2006) ve nitel yaklaşımın etkileşimli deseni altına bulunan durum çalışması yöntemi kullanılmıştır.

\section{Araştırma Grubu}

Araştırma; 2011-2012 öğretim yılı bahar döneminde Doğu Anadolu Bölgesi'nin nüfus bakımından orta ölçekli bir ilinde yer alan yer eğitim fakültesinin İlköğretim Bölümü Sosyal Bilgiler Eğitim Anabilim Dalı'nda öğrenin görmekte olan 30 dördüncü sınıf öğretmen adayı ile gerçekleştirilmiştir. Katılımcılardan 13’ü seçmeli olan matematik dersini almışken 
17'si bu dersi almamıştır. Araştırma grubunun belirlenmesinde öncelikle örnekleme birimi şubeler olmak üzere amaçlı örnekleme yöntemlerinden araştırma problemi ile ilgili olarak evrende yer alan çok sayıdaki durumdan tipik olan bir durumun belirlenerek bu örnek üzerinden bilgi toplanması (Büyüköztürk, Çakmak, Akgün, Karadeniz ve Demirel, 2011) şeklinde özetlenebilecek olan tipik durum örnekleme yöntemi kullanılarak araştırmaya katılacak şubeler belirlenmiştir. Ardından belirlenen şubedeki öğretmen adaylarında gönüllü olan araştırma kapsamına dahil edilmiştir.

\section{Veri Toplama Aracı}

Veriler katılımcıların düşüncelerini daha rahat bir şekilde ifade edebilecekleri ön görüsüyle araştırma grubu tarafından hazırlanan 5 soruluk görüşme formu yardımıyla toplanmıştır. Bu formda katılımcılardan herhangi bir demografik bilgi istenmeyerek katılımcıların görüşlerini rahatça ifade edebilecekleri bir ortam oluşturulmuştur. Ayrıca çalışmada veri toplama aracı olarak görüşme yerine görüşme formunun kullanılmasının amacı, araştırmacılardan birinin aynı zamanda katılımcıların matematik dersini yürütüyor olması nedeniyle form üzerinde katılımcıların görüşlerini daha objektif olarak ifade edebilecekleri düşüncesidir.

Görüşme formunun hazırlanması sürecinde öncelikle sosyal bilgiler öğretmen adayları ile görüşülmüş ve matematiğe karşı algıları yapılandırılmamış görüşmelerle açığa çıkarılmaya çalışılmıştır. Yapılan görüşmelerde öğretmen adaylarının matematiğe karşı korku ve kaygı geliştirdikleri görülmüş ve bu durum literatür ile desteklenerek kavramsal çerçeve oluşturulmuştur. Böylece başlangıçta yer alan 8 soruluk görüşme formu matematik eğitimi ve nitel araştırma konusunda uzman iki kişinin görüşüne sunulmuştur. Görüşme formu uzman görüşü alınarak benzer veya yakın olduğu düşünülen sorular formdan çıkarılarak görüşme formu 5 soruya düşürülmüş ve yine uzman görüşü dâhilinde iki soru cümlesi içeren sorular tekrar düzenlenmiştir. Nihai formdaki sorular aşağıdaki şekildedir:

- Matematik başarınız hakkında ne düşünüyorsunuz? Matematikte başarılı olmadığınızı düşünüyorsanız bunu neye bağllyorsunuz?

- Matematik fobiniz var mı varsa bu fobinin neden oluştuğunu düşünüyorsunuz?

- Matematik kaygınız var mı, varsa bunu neye bağlıyorsunuz?

- Keşke matematikte başarılı olsaydım şeklinde bir düşünceniz var mı? Neden?

- Sosyal Bilgiler öğretmenliği lisans programında matematik dersi yer almalı mı? Hangi dönemde ve kaç saat olmalıdır? 


\section{Verilerin Toplanması ve Analizi}

Hazırlanan görüşme formları tek bir uygulayıcı tarafından katılımcılarla önceden belirlenmiş bir zaman diliminde katılımcılara dağıtılmış ve katılımcıların doldurmaları için bir saatlik süre verilmiştir. Bu süre sonunda formlar toplanarak her bir katılımcıdan alınan görüşme formları numaralandırılmış ve veriler bilgisayar ortamına aktarılmıştır. Elde edilen verileri açıklayabilecek kavramlara ve ilişkilere ulaşabilmek (Yıldırım ve Şimşek, 2008) amacıyla veriler içerik analizine tabi tutulmuştur. Üç araştırmacı birbirinden bağımsız olarak gerçekleştirdikleri analizlerde öncelikle veriler birden fazla okunarak muhtemel kod ve kategoriler oluşturulmuştur. Sonrasında her bir katılımcının bireysel olarak oluşturduğu kod ve kategori listesini tüm araştırmacılar bir araya gelerek incelemiş, \%86 düzeyinde fikir birliğine varılıp; fikir ayrılıklarına düşüldüğü noktalar tartışılmıştır. Yapılan tartışmalar sonucunda verinin ait olduğu kategori belirlenmiş ve ortak bir payda oluşturulmuştur. Katılımcıların sorular bazında belirlenen kategorilere göre dağılımlarını gösteren tablolar oluşturulmuş, ayrıca bu aşamada çalışmada yer verilecek olan alıntılar da belirlenmiştir.

\section{Bulgular}

$\mathrm{Bu}$ bölümde elde edilen bulgular veri toplama aracında yer alan soruların sırasına göre sunulmuştur. Katılımcıların ifadelerine yer verirken dersi alan katılımcılar A, almayanlar B şeklinde kodlanmıştır.

1. Matematik başarını ve nedeni hakkında ne düşünüyorsunuz? sorusunun analizi sonucu ortaya çıkan bulgular Tablo 1' de verilmiştir.

Tablo 1 incelendiğinde hem bu dersi alanların hem de almayan katılımcıların cevaplarının analizleri sonucu başarısızım, orta derecede başarılıyım ve başarılıyım şeklinde üç kategori ortaya çıkmıştır. Dersi alan katılımcılardan \%69’u almayan katılımcılardan ise \%88'i ise başarısızım kategorisinin oluşmasına sebep olmuştur. Başarısızım kategorisinin içeriğini matematik öğretmeni, temel kötü, ilgi duymama, çalışmama, zamanla unutma ve sebep yok şeklindeki kodlar oluşturmaktadır. 
Tablo 1. Matematik başarınız ve nedeni hakkında ne düşünüyorsunuz? sorusuna verilen yanıtlar ve frekanslart

\begin{tabular}{|c|c|c|c|c|c|c|c|c|}
\hline Kodlar & \multicolumn{2}{|c|}{$\begin{array}{l}\text { Matematik Dersi Alan Öğrenci } \\
\text { kodları }\end{array}$} & \multicolumn{2}{|l|}{ (f) } & \multicolumn{2}{|c|}{$\begin{array}{l}\text { Matematik Dersi Almayan } \\
\text { Öğrenci kodları }\end{array}$} & $\begin{array}{l}\text { (f) } \\
\\
7\end{array}$ & \\
\hline 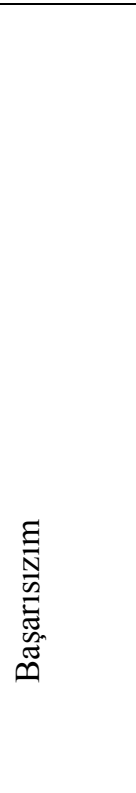 & $\begin{array}{l}\text { Matematik } \\
\text { Öğretmeni }\end{array}$ & $\begin{array}{l}\text { A-2, A-4, A-5, } \\
\text { A-7, A-9, A- } \\
12\end{array}$ & & 9 & $\begin{array}{l}\text { Temel kötü } \\
\text { Matematik } \\
\text { Öğretmeni } \\
\text { Çalışmamak } \\
\text { İlgi } \\
\text { duymamak } \\
\text { Zamanla } \\
\text { unutmak }\end{array}$ & $\begin{array}{l}\text { B-3, B-4, B-8, } \\
\text { B-9, B-11, B-14, } \\
\text { B-15 } \\
\text { B-5, B-10, B-12, } \\
\text { B-13, B-17 } \\
\text { B-1 } \\
\text { B-7 } \\
\text { B-16 }\end{array}$ & $\begin{array}{l}1 \\
1\end{array}$ & 8 \\
\hline 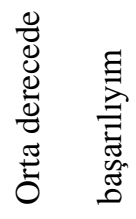 & - & $\begin{array}{l}\text { A-6, A-13, } \\
\text { A-11 }\end{array}$ & 3 & 23 & - & B-2 & & \\
\hline 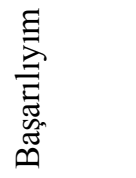 & - & A-1 & 1 & 8 & - & B-6 & & \\
\hline
\end{tabular}

Dersi alan katılımcılardan 6's1, dersi almayan katılımc1lardan ise 5' i matematik başarısızlığının sebebini geçmişte (ilköğretim-ortaöğretim) matematik öğretmeni ile ilgili yaşantılarına bağlamıştır. Bu yaşantılar, matematik öğretmenlerinin yapısı (aşırı otoriter, kuralcı ve baskıcı) veya öğretmenlerinin mesleki yeterlikleri (alan bilgisi, pedagojik bilgi) ile ilgili öğrencilerin algıladıkları problemlerdir. Örneğin A-2'nin “Başarılı olduğum söylenemez. İlköğretim matematik ögretmenimizin yapısından kaynaklanıyor diye düşünüyorum.”, A-5’in “...başarısızlığımı ilkokul matematik öğretmenime bă̆lıyorum. Korkusundan bildiklerimizi de yapamazdık.” ve B-10’nun “Matematik dersinde pek başarılı bir ögrenci değilim. Matematikte başarılı olmamamın sebebi ortaokuldaki hocamın 
matematik dersinde aşırı kuralcı ve baskıcı olması anlatış tarzı ezberci olması matematikten başarısız olmama sebep olmuştur. ” şeklindeki ifadeleri bu kodun uygun örneklerindendir.

Başarısızım kategorisinde dersi alan katılımcılardan 1'inin, dersi almayan katılımcılardan ise 7'sinin oluşturduğu temel kötü kodu, matematik dersinin temelinin ilk atılmaya başlandığı yıllarda herhangi bir problem kaynaklı algılama sorununu (eksik, yanlış, hatalı algılama veya algılayamama) ifade etmektedir. Bu koda B-4'ün “Matematik başarım kötüydü. Bunun sebebi ise temelde iyi bir ĕgitim görmememizdi.” ve B-8'in “Alt yapı eksikliğine bağllyorum." ifadeleri birer örnektir.

B-1'in “Hiç çalışmayı denemedim.” şeklindeki ifadesi çalışmama, B-7’nin “Başarılı olmamamın sebebi ilgi duymamam ve yeterince üzerinde yoğunlaşmamam.” şeklindeki ifadesi ilgi duymama ve B-16'nın “Matematik dersinde ilk ögretimde başarıllydım fakat lisede sözel bölümü seçtikten sonra iyice unuttum ve daha sonra bir ön yargl oluştu." şeklindeki ifadesi ise zamanla unutma kodunu oluşturmuştur. A-3 ve A-8 kodlu katılımcılar ise, kendilerini matematikte başarısız görmekle beraber bu başarısızlığın sebebi hakkında herhangi bir yorum yapmamaktadirlar.

Dersi alan 3 ve dersi almayan 1 katılımcının oluşturduğu orta derecede başarllıyım kategorisi matematiği azda olsa bilen ancak yeteri kadar geliştiremediğini düşünen katılımcıların oluşturduğu kategoridir. A-6’nın “Matematik konusunda orta derecede başarllıyım. Matematiği seviyorum başaracă̆ıma da inanıyorum ama ezber yaptığım için unutuyorum.” ve A-13'ün “Orta düzeyde bir matematik seviyem var. Yeteri derecede test çözmüyorum. Gerekli önemi matematiğe göstermiyorum." şeklindeki ifadeleri bu kod için bir örnektir. Dersi alan ve almayan gruptaki katılımcılardan 1'i başarılıyım kategorisinin oluşmasına sebep olmuştur. Bu katılımcılar matematik başarıları hakkında öz yeterlik duygusuna sahip olup başarılı oldukları ifade etmişlerdir.

\section{2. “Matematik fobiniz var mı varsa bu fobinin neden oluştuğunu} düşünüyorsunuz?” sorusunun analizi sonucu ortaya çıkan bulgular Tablo 2' de verilmiştir.

Tablo 2 incelendiğinde fobim var (12), fobim yok (14) ve klsmen var (4) şeklinde üç kategori oluşmuştur. Fobim var kategorisini başarısızlık, çalışmama, anlayamama ve sıkıcı gelme, düşük öz yeterlik, sebep yok ve düşük sayısal zekâ algısı şeklindeki kodlar oluşturmuştur. 
Tablo 2. Matematik fobiniz var mı varsa bu fobinin neden oluştuğunu düşünüyorsunuz? sorusuna verilen yanıtlar ve frekansları

\begin{tabular}{|c|c|c|c|c|c|c|c|c|}
\hline Kodlar & $\begin{array}{l}\text { Matematik De } \\
\text { kodları }\end{array}$ & si Alan Öğrenci & (f) & $\%$ & $\begin{array}{l}\text { Matematik D } \\
\text { kodları }\end{array}$ & i Almayan Öğrenci & (f) & $\%$ \\
\hline 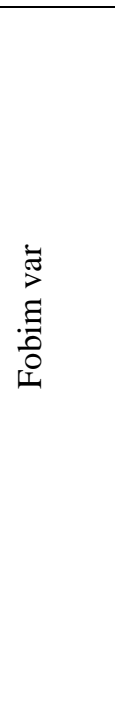 & $\begin{array}{l}\text { Düşük sayısal } \\
\text { zekâ algısı } \\
\text { Çalışmama }\end{array}$ & A-13 & 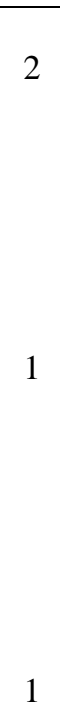 & 31 & $\begin{array}{l}\text { Başarısızlık } \\
\text { Çalışmama } \\
\text { Anlayamama } \\
\text { ve Sıkıcı } \\
\text { Gelme } \\
\text { Düşük öz } \\
\text { yeterlik } \\
\text { Sebep Yok }\end{array}$ & $\begin{array}{l}\text { B-11, B-14, B-15, } \\
\text { B-17 } \\
\text { B-1 } \\
\text { B-10 } \\
\text { B-16 } \\
\text { B-13 }\end{array}$ & 1 & 47 \\
\hline 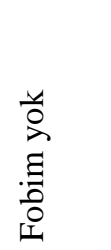 & - & $\begin{array}{l}\text { A-1, A-3,A-4, } \\
\text { A-6, A-11, A-12 }\end{array}$ & 6 & 46 & & $\begin{array}{l}\text { B-2, B-5, B-6, B- } \\
\text { 7, B-8, B-9, B- } \\
12\end{array}$ & 7 & 41 \\
\hline 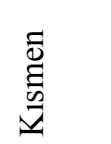 & - & A-2, A-7 & 2 & 15 & & B-3, B-4 & 2 & 12 \\
\hline ది & - & A-5 & 1 & 8 & - & - & - & - \\
\hline
\end{tabular}

Fobim var kategorisi incelendiğinde başarısızım kodu alında dersi alan katılımcılardan 2'si dersi almayan katılımcılardan ise 4'ü fobilerinin nedenini sürekli başarısızlıkla sonuçlanan deneyimlerine bağlamışlardır. A-8'in “Bence benim fobim olduğu gibi sözel mezunu olan herkesin matematik fobisi vardır. Benim için bunun en büyük nedeni bir kez ya da birkaç kez yapamayınca bir daha yapamayacă̆ıma inanmak, çevremde de bu yönde tepkiler almak." ve B-11'in "Evet, var çünkü uğraştığımda sonuç hep yanlış çıkıyor” şeklindeki ifadeleri bu kod için birer örnek niteliğindedir. Bu kategorinin diğer bir kodunu oluşturan çalışmama kodu her iki grupta da birer katılımcının ifadesi ile oluşmakta olup; hiç 
çalışmamaktan veya yeteri kadar çalışmamaktan kaynaklı fobiler anlamını taşımaktadır. Bu koda örnek olarak A-13’ün "Yapamama sıkıntısı var. Matematik dersine çalışmamaktan olduğunu düşünüyorum” ve B-1'in “Evet var. Hiç çalışmayı denemediğim için” şeklindeki ifadeleri verilebilir. A-9’ un “Fobi maalesef her sözelci de olduğu gibi bende de var. Çünkü sayısal zekâm çok düşük.” şeklindeki ifadesi “düşük sayısal zeka algısı” , B-10’nun “Evet matematiğe karşı bir fobim var. Matematikte başarısı olmam, dersi anlayamamam ve bana sıkıcı gelmesinden dolayı.” şeklindeki ifadesi anlayamama ve sıkıcı gelme ve B-16'nın “Evet var. Uzun süredir çalışmadiğım için yapamayacağımı düşünüyorum." şeklindeki ifadesi ise düşük öz yeterlik kodunu oluşturmuştur.

Dersi almayan gruptaki katılımcılardan 1'i ise matematiğe karşı bir fobisi olduğunu ifade ederken bunun sebebini bildirmemiştir. Matematik fobisinin kısmen olduğunu bildiren 4 katılımcı fobilerinin bazı konularda olduğunu veya önceden varken şimdi geçtiğini ifade eden katılımcılardır. Fobim yok kategorisini ise dersi alan katılımc1lardan 6 almayanlardan 8 katılımcı oluşturmuştur. Bu katılımcılar fobileri olmadığ gibi matematiği sevdiklerini ve matematikle uğraşmaktan zevk aldıklarını ifade etmişlerdir.

3. “Matematik kaygınız var mı, varsa bunu neye bağlıyorsunuz?” sorusunun analizi sonucu ortaya çıkan bulgular Tablo 3' de verilmiştir.

Tablo 3 incelendiğinde dersi alan ve almayan katılımcılar, kaygım var (21), kaygım yok (5), kaygım var ama azaltılabilir (3), ve kısmen var (1) şeklinde dört kategori oluşturmuştur. Kaygım var kategorisinde sınav kaygısı, her zaman gerekli olma, hiç öğrenememe, temel eksikliği, öğrenip unutma, işlem korkusu ve sebep yok şeklindeki kodlar yer almaktadır. 
Tablo 3. Matematik kaygınız var mi, varsa bunu neye bağllyorsunuz? sorusuna verilen yanitlar ve frekanslart

\begin{tabular}{|c|c|c|c|c|c|c|c|c|}
\hline Kodlar & $\begin{array}{l}\text { Matematik De } \\
\text { kodları }\end{array}$ & si Alan Öğrenci & (f) & $\%$ & $\begin{array}{l}\text { Matematik Deı } \\
\text { kodları }\end{array}$ & Almayan Öğrenci & (f) & $\%$ \\
\hline 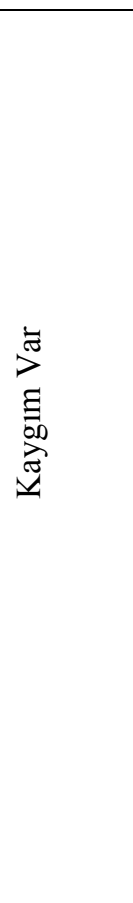 & $\begin{array}{l}\text { Sinav Kaygis1 } \\
\text { (Kpss) } \\
\text { Temel } \\
\text { Eksikliği } \\
\text { Öğrenip } \\
\text { Unutma } \\
\text { Hiç } \\
\text { Öğrenememe }\end{array}$ & $\begin{array}{l}\text { A-3, A-8, A-9, } \\
\text { A-13 } \\
\text { A-5 }\end{array}$ & 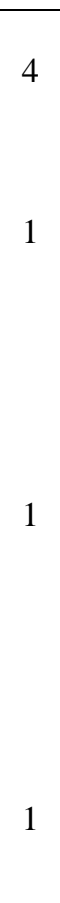 & 54 & $\begin{array}{l}\text { Her zaman } \\
\text { gerekli olma } \\
\text { Hiç } \\
\text { öğrenememe } \\
\text { Sınav kaygısı } \\
\text { (Kpss) } \\
\text { Sürekli } \\
\text { başarısız olma } \\
\text { İşlem korkusu } \\
\text { Sebep Yok }\end{array}$ & $\begin{array}{l}\text { B-3, B-4, B-10, } \\
\text { B-12 } \\
\text { B-11, B-16, B-15, } \\
\text { B-17 } \\
\text { B-1, B-2, B-9 } \\
\text { B-14 } \\
\text { B-7 } \\
\text { B-13 }\end{array}$ & 4 & 82 \\
\hline 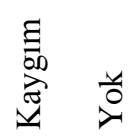 & & A-1, A-11 & 2 & 15 & - & B-5, B-6, B-8 & 3 & 18 \\
\hline 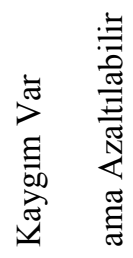 & - & A-2, A-4, A-7 & 3 & 23 & - & - & - & - \\
\hline 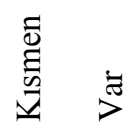 & - & A-12 & 1 & 8 & - & & - & - \\
\hline
\end{tabular}

Kaygım var kategorisi incelendiğinde sınavlarda (özellikle KPSS) sürekli karşılaşma durumu ile yüzleşen ve kaygının oluşmasına neden olan sınav kaygısı kodunu dersi alan katılımcılardan 4'ü dersi almayan katılımcılardan ise 3'ü oluşturmaktadır. A-8'in "Var gireceğim sınavlarda sürekli karşıma çıktı̆̆ için bu kaygıyı taşıyorum.” ve B-2' nin "Matematik kaygım KPSS için var. Çünkü sevdiğim ve tercih ettiğim mesleğe KPSS sinavını geçip atanmak için matematik engeline takılabilirim diyerek içimde ister istemez bir kaygı oluşuyor." şeklindeki ifadeleri bu kod için birer örnek niteliğindedir. Bu kategorinin diğer bir 
kodunu oluşturan her zaman gerekli olma sadece dersi almayan 4 katılımcı tarafından oluşturulmuş olup matematik ile günlük hayatta sürekli karşılaşılması nedeniyle kaygı yaşadıkları ifade edilmiştir. Örnek olarak B-10 düşüncesini "Matematik kaygım var. Matematik sadece ders olarak değil de günlük hayatta da karşıma çıktı̆̆ı için matematiğe her zaman kaygıyla bakmışımdır” şseklinde ifade etmiştir. Dersi alan katılımcılardan 1'inin ve dersi almayan katılımcılardan da 4'ünün oluşturduğu hiç ögreneme kodu ya matematiği deneyimlerine dayanarak hiç öğrenemediklerini ya da sezgileri ile matematiğe ön yargılı yaklaşıp hiç öğrenemeyeceklerini düşünmeleri anlamını taşımaktadır. Bu koda örnek olarak A-10’nun “Kaygım evet var, ögrrenemediğim için.” ve B-17’ nin “Elbette var. Sanki hiç matematik yapamayacă̆ım gibi geliyor." şeklindeki ifadeleri verilebilir. Dersi alan katılımcılardan A-5' in 'Matematiği ögrenmede doğrusu kaygım var. Bunun nedeni ise temelimin olmamasıdır. " şeklindeki ifadesi kaygının sebebinin temel eksikliği olduğunu ve A6' nın "Tek kaygım öğrendiğimi unutmaktır. Bununla ilgili ders görmediğim için o zaman öğrenip ihtiyacım bittiğinde unutmaktır.” şeklindeki ifadesi ile öğrenmekten çok ögrenip unutmaktan kaygı duyduğunu göstermektedir. Diğer taraftan dersi almayan katılımcılardan B14' ün "Kaygım var. Hep başarısız olmaktan kaynaklanıyor." şeklindeki ifadesi sürekli başarısız olma, B-7’ nin “Kaygım var, işlemler beni korkutuyor.” ş̧eklindeki ifadesi işlem korkusu ve B-13'ün matematiğe karşı bir kaygısının olduğunu ifade etmesi fakat bunun sebebini bildirmemiş olması sebep yok kodlarını oluşturmuştur.

Kaygım yok kategorisini dersi alan katılımcilardan 2 almayanlardan 3 katılımc1 oluşturmuştur. $\mathrm{Bu}$ katılımcılar matematiğe karşı bir kaygı yaşamadıklarını ifade edip, herhangi bir açıklamada bulunmamışlardır. Kaygım var ama azaltılabilir kategorisini ise sadece dersi alan katılımcıların 3'ü oluşturmaktadır. A-2' nin "Var ama çalışınca aşılabildiğine inanıyorum." şeklindeki ifadesi alınan veya alınacak olan eğitim ile bu kaygının yenilebileceğini göstermektedir. Matematik kaygısına ilişkin kısmen var kategorisi, sadece dersi alan katılımcılardan 1' inin bazı konularda veya bazı durumlarda kaygısının ortaya çıktığını ifade etmesi sonucu oluşturulmuştur.

\section{4. “Keşke matematikte başarılı olsaydım şeklinde bir düşünceniz var mı,}

neden?” sorusunun analizi sonucu ortaya çıkan bulgular Tablo 4' de verilmiştir.

Tablo 4 incelendiğinde hem bu dersi alanların hem de almayan katılımcıların cevaplarının analizleri sonucu var ve yok şeklinde iki kategori ortaya çıkmıştır. Dersi alan katılımcılardan \%92' sinin almayan katılımcılardan ise \%76' sının keşke matematikte başarılı olsaydım şeklinde bir düşüncelerinin olduğu belirlenmiştir. Var kategorisinin içeriğini günlük 
yaşamdaki gereklilik, kariyer kaygısı, farklılık katması, kendini ispatlama ve sebep yok şeklindeki kodlar oluşturmaktadır.

Tablo 4. Keşke matematikte başarılı olsaydım şeklinde bir düşünceniz var mı, neden? sorusuna verilen yanttlar ve frekanslart

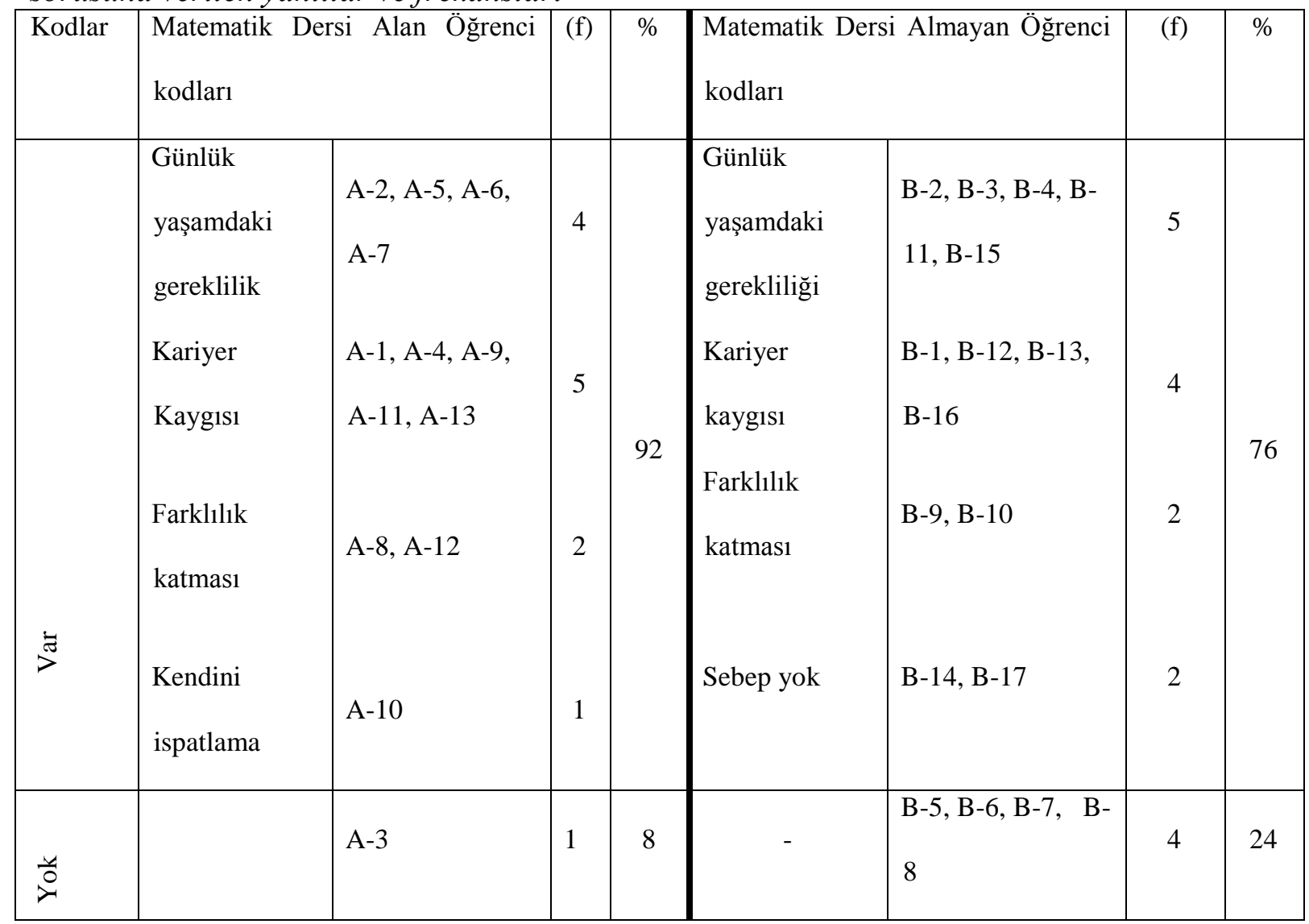

Katılımcıların matematik dersini bilmek istemelerinin temelinde yer alan kodlardan günlük yaşamdaki gereklilik kodu katılımcıların matematik ile günlük hayatta sık sık karşılaşmaları dolayısıyla matematiğe ihtiyaç duymaları anlamına gelmektedir. Bu kodu dersi alan katılımcılardan 4, almayanlardan ise 5 katılımcının cevapları oluşturmuştur. A-7' nin “Kesinlikle var. Çünkü hayatın her alanında matematiğin gerekli olduğunu düşünüyorum.” B-11'in "Evet çok var, çünkü her yerde karşımıza çıkıyor ve bunun için de matematiği bilmek lazım." şeklinde örnekler bu kodun örnek ifadelerindendir. Var kategorisinin günlük yaşamdaki gereklilik kodu ile aynı frekansa sahip bir diğer kodu da kariyer kaygısıdır. Bu kodu dersi alan 5, almayan ise 4 katılımcının cevapları oluşturmuştur. Kariyer kaygısı kodu katılımcıların önüne çıkan veya çıkacak olan bütün sınavlarda var olan matematiği dolayısıyla matematik yapma gerekliliğini ve böylece istenilen kariyerlere, hedeflere ulaşma firsatını elde

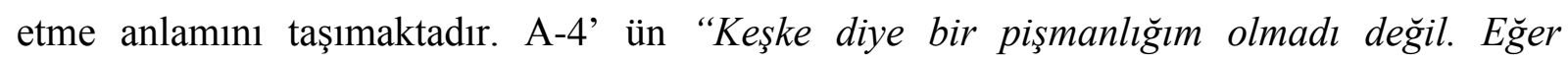


üniversite sınavında sosyalin yanında matematik yapsaydım daha iyi bir bölüme gidebilirdim.”, B-13’ün “Keşke bilseydim. Yaşantım, idealim, her şeyim şimdi çok farklı bir noktadaydl.” ve B-16'nın “...Çünkü matematik atanmam için yapmak zorunda olduğum en önemli ders.” şeklindeki ifadeleri bu kod için verilebilecek örneklerdendir. Dersi alan ve almayan toplamda 4 katılımcının cevapları ile oluşan farklılık katması kodu ise, matematik bilmenin ve yapmanın insanları zihinsel olarak farklı kılması (yetenekli ve zeki) ve toplumun matematik bilen ve yapabilen insanlara bakış açısının da diğer insanlardan farklı olması anlamını taşımaktadır. Bu kod için verilebilecek örnekler A-8'in "Ben hep matematik yapabilen kişilerin yerinde olmayı istemişimdir. Nedeni; sanki insana farklılık katıyor" ve B10'un “Bir sözelci olarak insanların bize bakış açıları hep farklı olmuştur. Bu bakış açılarını değiştirebilirdim.” şeklindeki ifadeleridir. Dersi almayan iki katılımcı matematik dersini bilmek istediklerini ifade ederken bunun sebebini belirtmemişlerdir. Kendini ispatlama kodu ise A-10'nun "Evet, var, nedeni babama matematiği yapabildiğimi göstermek için." şeklindeki ifadesi sonucu oluşmuştur.

Dersi alan gruptan 1, almayan gruptan ise 4 katılımcı matematik dersini ya biliyor ya da gerek duymamasından kaynaklı keşke matematiği bilseydim şeklinde bir düşünce taşımamaktadır.

\section{5. “Matematiğin günlük hayatta bir işleve sahip olduğunu düşünüyor} musunuz? Açıklayınız.” sorusunun analizi sonucu ortaya çıkan bulgular Tablo 5' de verilmiştir.

Tablo 5 incelendiğinde "Matematiğin günlük hayatta bir işleve sahip olduğunu düşünüyor musunuz? Açıklayınız” sorusuna verilen cevaplara ilişkin veriler incelediğinde dersi alan gruptaki katılımcıların \%92'si, dersi almayan gruptaki katılımcıların ise \%53’ü günlük hayatta matematiğin bir işleve sahip olduğunu düşünmektedir. 
Tablo 5. Matematiğin günlük hayatta bir işleve sahip olduğunu düşünüyor musunuz? sorusuna verilen yanitlar ve frekanslart

\begin{tabular}{|c|c|c|c|c|c|c|c|c|}
\hline Kodlar & $\begin{array}{l}\text { Matematik D } \\
\text { kodları }\end{array}$ & si Alan Öğrenci & (f) & $\%$ & $\begin{array}{l}\text { Matematik De } \\
\text { kodları }\end{array}$ & i Almayan Öğrenci & (f) & $\%$ \\
\hline 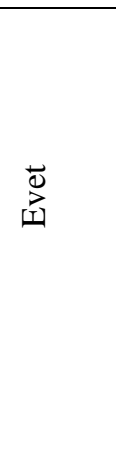 & $\begin{array}{l}\text { Hayatı } \\
\text { kolaylaştırma } \\
\text { Hesap kitap } \\
\text { Sebep yok }\end{array}$ & $\begin{array}{l}\text { A-2, A-3, A-4 } \\
\text { A-5, A-6, A-7, } \\
\text { A-8, A-12, A- } \\
13 \\
\text { A-1, A-11 } \\
\text { A-10 }\end{array}$ & 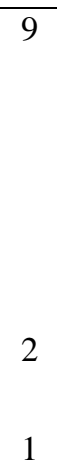 & 92 & $\begin{array}{l}\text { Hayatı } \\
\text { kolaylaştırma } \\
\text { Hesap kitap } \\
\text { Sebep yok }\end{array}$ & $\begin{array}{l}\text { B-3, B-6,B-9 } \\
\text { B-10 B-14 } \\
\text { B-2, B-11, B-16 } \\
\text { B15 }\end{array}$ & 3 & 53 \\
\hline 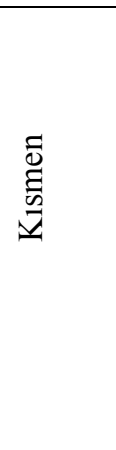 & $\begin{array}{l}\text { Sadece } \\
\text { sinavlar }\end{array}$ & A-9 & 1 & 8 & $\begin{array}{l}\text { Hesap kitap } \\
\text { Sebe } \\
\text { p yok } \\
\text { Hayat } \\
1 \text { kolaylaştırma }\end{array}$ & $\begin{array}{l}\text { B-1, B-4, B-12, } \\
\text { B-13, B-17 } \\
\text { B-5, B-8 } \\
\text { B-7 }\end{array}$ & 5 & 47 \\
\hline
\end{tabular}

Matematiğin bir işleve sahip olduğunu düşünen katılımcıların oluşturduğu evet kategorisi incelendiğinde; en yüksek frekansa sahip olan hayatı kolaylaştırma kodu 14 katılımcının cevabı ile ortaya çıkmıştır. Bu kodu oluşturan katılımcılar matematiğin günlük hayattaki gerekliliği üzerine vurgu yaparak kolaylaştırıcı etkisinden söz etmişlerdir. A-7' nin “...elbette kolaylaştırıyor. Çok basit durumlarda bile basit bir matematik bilgisine sahip olamama zaman zaman sıkıntıya soktuğu bir gerçek” ve B-10’un “Matematiğin günlük hayatı kolaylaştırdı̆̆ını düşünüyorum. İnsanların günlük hayatta uğraşacakları işler için ve hayatı daha kolay kllmak için matematiğin günlük hayatta gerekli olduğunu düşünüyorum.” şeklindeki ifadeleri bu kod için birer örnek teşkil etmektedir. Evet kategorisindeki hesap kitap kodu ise 5 katılımcının cevapları sonucu oluşturulmuş olup bu kodun içeriğini dört işlem becerisi temeline dayalı günlük yaşamdaki rutin hesaplamalar oluşturmaktadır. A11'in "Matematiğin günlük hayatı kolaylaştırdığını düşünüyorum bir hesap makinense bağlı kalmak gerçekten insanlar için üzücü bence.” ve B-2’nin “...marketten üç tane ekmek alırken bile basitte olsa bir matematiksel işlem gerekiyor." ş̧eklindeki ifadeleri kodun 
örneklerindendir. Evet kategorisini oluşturan ve bu dersi alan ve almayan grupta birer kişi olmak üzere toplam iki kişi ise matematiğin günlük hayatta neden bir işleve sahip olduğu konusunda herhangi bir yorum belirtmemiştir.

Klsmen kategorisi incelendiğinde ise dersi alan gruptaki A-9' un 'Bence matematik KPSS ve ÖSS gibi sınavlar hariç günlük hayatımda hiçbir işime yaramıyor" ifadesi matematiğin sadece sınavları aşmak için gerekli bir ders olduğunu izlenimi ile beraber sadece sınavlar kodunu oluşturmuştur. Yine klsmen kategorisindeki hesap kitap kodu, matematiğin sadece günlük yaşamda dört işlem becerisi gerektiren hesaplamalar için gerekli olduğunu, bunun dışında herhangi bir işleve sahip olmadığını düşünen ve bu dersi alamayan öğrencilerden 5' inin oluşturduğu koddur. B-12'nin “Matematiğin hayatı kolaylaştırdiğg net bir şekilde ortada fakat günlük hayatta bakkal hesabı dediğimiz rutin olaylar dışında çok da kullanıldığını sanmıyorum." şeklindeki ifadesi de bu kodun güzel bir örneğidir. Kısmen kategorisinde 2 kişi bu konuda herhangi bir fikir belirtmeyerek, sebep yok kodunu, B-7'nin “Bazen işe yarıyor kolaylaştırıyor." şeklindeki ifadesi de hayatı kolaylaştırma kodunu oluşturmuştur.

\section{Sosyal Bilgiler öğretmenliği lisans programında matematik dersi yer} almalı mıdır? Eğer yer almalıdır diyorsanız sizce hangi dönemde yer almalıdır? sorusunun analizi sonucu ortaya çıkan bulgular Tablo 6' da verilmiştir.

Tablo 6. Sosyal Bilgiler ögretmenliği lisans programında matematik dersi yer almalı mıdır? Ĕger yer almalıdır diyorsanı sizce hangi dönemde yer almalıdır? sorularına verilen yanıtlar ve frekansları

\begin{tabular}{|l|l|l|l|l|}
\hline & Matematik dersini alan kat1lımc1lar & $\%$ & Matematik dersini almayan kat1lımc1lar & \\
\hline Evet & A-1, A-3, A-4,A-6,A-7, A-8,A-11, & & B-2, B-4, B-8 (Her dönem), B-3 (sadece & \\
& $\begin{array}{l}\text { A-12, A-13 (Her dönem), A-2 (2. } \\
\text { Sinıftan itibaren), A-5 (-),A-9 }\end{array}$ & 92 & $\begin{array}{l}\text { 1. sinıfta), B-6 (3. sinıfta), B-7, B-10, } \\
\text { B-15 (-), B-11 (Son dönem), B-12, B- }\end{array}$ & 0 \\
& $(1$ dönem) & & 13, B16 (Son sinıfta), & \\
\hline Hayır & A-10 & 8 & B-1, B-5, B-9, B-14, B-17 & \\
\hline
\end{tabular}

Tablo 6 incelendiğinde dersi alan katılımcıların \%92'si,dersi almayan katılımcıların ise \% 60’1 sosyal bilgiler öğretmenliği programında matematik dersinin yer alması gerektiğini belirtmiştir. Dersi alan gruptan 9, almayan gruptan ise 3 katılımcı matematik dersinin her 
dönem seçmeli ders olarak programda yer alması gerektiğini belirtirken; son sınıf (3), 1 . sinıftan itibaren (1), 2. sinıftan itibaren (1), 3. sinıfta (1), son dönem (1), sadece bir dönem (1) ve yorumu olmayanlar (3) şeklindeki kodlarda ortaya çıkmıştır. Evet kategorisini oluşturan katılımcılar sınavlarda gerekli olması, ilişkilendirmeye imkan tanıması, her öğretmenin matematik bilme gerekliliği şeklindeki nedenlerden ötürü bu dersin programda yer alması gerektiğini düşünmektedirler. $\mathrm{Bu}$ kategoriye ilişsin örnekler A-5: "Sosyal bilgiler programında matematiğin olması gerekiyor. Çünkü içeriğinde matematik var.” A-12: “Ĕ̆gr KPSS' ye giriyorsak ve KPSS' de de matematik varsa bence her dönem olmall. Çünkü bizi bu dersten sorumlu tutuyorlarsa bu dersi de bize vermeliler.” B-7: “ Bence olmamalı,...düzeyimize göre olmalı sadece sosyal bilgiler derslerindeki ilişkilendirmeler için gerekli. Örneğin harita bilgisi için.” B-15: "Lisans programında yer almalı çünkü bir öğretmenin az da olsa matematik bilgisine sahip olması gerekir. ” şeklinde sıralanabilir.

Matematik dersinin sosyal bilgiler öğretmenliği lisans programında yer alması gerektiğini düşünmeyen ders alan gruptan 1, almayan gruptan ise 6 katılımcıdır. Bu öğrencilerin ifadeleri ise; A-10: "Bence kesinlikle yer almamalı çünkü bu bölümde matematik olmadiğg için geldim.” B-9: “Sosyal bilgiler öğretmenliği lisans programında matematik dersi yer almamalıdır. Çünkü bu bölüme gelenlerin hepsi sözel çıkışlıdır matematik olacaksa ĕger sayısal eşit ağırlık çıkışlı olanlar alınmalıdır. ”şeklinde örneklendirilebilir.

\section{Sonuç ve Tartışma}

Çalışma, sosyal bilgiler öğretmenliği bölümünde seçmeli bir ders olarak verilen ve bu dersi alan ve almayan sosyal bilgiler öğretmen adaylarının kaygı, fobi ve algıladıkları matematik başarısı açısından matematiğe karşı tutumlarını ortaya koyabilmek amacını taşımaktadır.

Bulgular incelendiğinde dersi alan katılımcılardan \%69' u almayanlardan ise \%88' i kendini matematikte başarısız olarak nitelendirmektedir. Dersi almayan katılımcıların daha büyük yüzde ile kendini başarısız hissetmesi, ayrıca dersi alan ve almayan her iki grubunda yine büyük bir yüzde ile kendilerini başarısız olarak nitelendirmesi Araujo (2008) tarafından sosyal bilgiler ve coğrafya öğretmen adaylarının çoğunluğunun matematik ile ilgili öğrenme güçlükleri, olumsuz deneyimler ve başarısızlıklar yaşadıkları şeklindeki sonucu ile benzerlik göstermektedir. Katılımcılar bu başarısızlığının sebeplerini matematik öğretmenlerine, atılamayan matematik temellerine, çalışmamalarını, ilgi duymamaları gibi sebeplere bağlamışlardır. Bu sebepler Keçeci (2011), Bekdemir (2007) ve Byrd’da (1982) matematik kaygısının sebeplerini araştıran çalışmalarında tespit ettikleri ve genel olarak alandan, eğitim 
ve eğitmenden kaynaklanan sebeplerle oldukça yakın benzerlik göstermektedir. Özellikle A5’in “...başarısızlı̆̆ımı ilkokul matematik öğretmenime bağllyorum. Korkusundan bildiklerimizi de yapamazdık." şeklindeki ifadesi, benzer çalışmalarda da ifade edilmiş olup; bu durum öğretmenin olumsuz tutum ve uygulamaları ile açıklanabilir (Bekdemir, 2007; Bekdemir vd., 2004). Katılımcıların belirttikleri başarısızlık sebepleri dikkate alındığında, geçmiş yaşantıları sonucu edindikleri olumsuz inanışların etkisinde oldukları görülmektedir. Matematik dersini alan ve almayan her iki grupta da sadece birer kişinin kendini başarılı olarak nitelendirmesi sosyal bilgiler öğretmenliği programında öğrenim gören öğretmen adaylarının algılanan matematik başarısının düşüklüğü hakkında bir bilgi vermektedir.

İkinci sorunun bulguları incelendiğinde matematik dersini alan grupta \%31, almayan grupta ise \%47 katılımcı matematik fobisi olduğunu düşünmektedir. Bu dersi almayan grup, dersi alan gruba göre daha yüksek bir yüzde ile matematik fobisine sahiptir. Bu durum dersi alan gruptaki katılımcıların dersi almayan gruptaki katılımcılara göre kendini daha başarısız hissetmesi şeklindeki birinci soruda açığa çıkan bulgunun devamı şeklinde karşımıza çıkmaktadır. Buradan matematik başarısızlığı beraberinde matematik fobisini de getiriyor şeklinde algılayabiliriz ki zaten katılımcılar fobilerinin en büyük kaynağı olarak başarısızlıklarını göstermektedirler. Bunu sonucunda başarısızlığı fobiye, fobiyi başarısızlığa sürükleyen bir düzenek olarak görmek mümkün olabilir. Ayrıca başarısızlık olarak ortaya çıkan fobi sebebi aslında, organizmanın ne kadar çaba harcarsa harcasın durumu değiştiremeyeceğini öğrenerek pasif kalması ve bu pasifliği de tüm istenmeyen durumlara genellemesi (Seligman ve Maier, 1967'den akt. Senemoğlu, 2011, s.104) şeklinde psikolojide yer alan ve öğrenilmiş çaresizlik olarak ifade edilen bir klasik koşullanma durumdur. A-8'in “...bir kez ya da birkaç kez yapamayınca bir daha yapamayacağıma inanmak” ve B-11'in “Evet, var çünkü uğraştığımda sonuç hep yanlış çıkıyor” ifadeleri bu durumu destekler niteliktedir. Hergenhahne (1988) genel olarak pasiflik, korku, depresyon ve sonucu kabul etmeye isteklilik gibi etmenlerin öğrenilmiş çaresizliğin belirtileri olduğunu söylemektedir. Fobiyi de korku ve depresyon gibi olumsuz yapıların içinde düşünürsek, fobinin öğrenilmiş çaresizliğin yani başarısızlığın bir belirtisi olduğunu açıkça söylenebilir. İkinci sorunun bulgularında, dikkat çeken başka bir nokta matematik dersini alan öğrencilerin \%46' sının almayanların ise \% 41' inin fobisi olmadığını söylemesidir. Yine birinci sorunun matematikte başarısızlık algısı yaşayan yüksek yüzde oranı düşünüldüğünde, matematikte başarısız olan ancak fobiye sahip olmayan katılımcıların olduğu da ulaşılan bir sonuçtur. 
Üçüncü sorunun bulguları incelendiğinde, matematik dersini alan katılımcılarda matematik kaygısı \%54 iken; almayanlarda ise \% 82 olarak belirlenmiştir. Bu oranlar göz önüne alındığında matematik dersini seçmeyenler daha yüksek kaygı oranına sahip olduğu görülmüştür. Bu sonuç Reglin’in (1990) matematik korkusunun ve kaygısının matematik başarısını olumsuz yönde etkilediğini ve matematikten kaçmaya neden olduğu ifadesi ile ilişkilidir. Üçüncü sorunun bulguları birinci sorunun bulguları ile ilişkilendirildiğinde düşük başarı algısına sahip olan öğrencilerin fobi ve kaygı durumlarının var olduğu aksine kendini başarılı algılayanların fobi ve kaygı durumlarının ya kısmen olduğu ya da olmadığı Tablo 1, 2 ve 3'e bakılarak söylenebilir. Bu sonuç ise Townsend, Moore, Tuck ve Wilton'un (1998) öğrencilerin matematik dersinde düşük başarı göstermelerinin korku ve kaygı düzeylerini yükselttiğini bu nedenle de öğrencilerin sıkıntı ve zorluk çekmeleri bulgusu ile paraleldir. Kaygıyı oluşturan sebepler arasında sınav kaygısı ve hiç öğrenememe kodlarının matematik dersini alan ve almayan katılımcılarda ortak olduğu görülmüş; diğer taraftan dersi alanlarda temel eksikliği ve öğrenip unutma, dersi almayanlarda ise her zaman gerekli olma, sürekli başarısız olma ve işlem korkusu ortaya çıkmıştır. Kaygıyı oluşturan en büyük etmenler arasında sınav kaygısı yer almaktadır. Üniversite öğrencilerinde sınav kaygısı, ortak ve potansiyel ciddi bir problem şeklinde üniversite giriş sınavlarından itibaren başlayan ve üniversite öğrenimleri süresince farklı bireylerde farklı şekillerde yaşanmaya devam eden bir durumdur (Erözkan, 2004). Literatürde sınav kaygısı ile ilgili yapılan çalışmalarda sınav kaygısının düşük test performansı ile birleştiğini (Hembree, 1988; Seipp, 1991) ve dolayısıyla düşük akademik başarısına neden olduğu belirlenmiştir. Sınav kaygısı ile öğrenilmiş çaresizlik ve akademik başarısı arasındaki var olan bu ilişki (Gündoğdu, 1994) bu durumun ayrıca alınmasını önemli kılmaktadır. Kaygıya neden olan ve B-17’nin “Elbette var. Sanki hiç matematik yapamayacă̆ım gibi geliyor." örneğindeki gibi ifadelerin oluşturduğu hiç ögrenememe etkeni ise Hoffman'1n (2010) bence yapabilirim ama denemekten korkuyorum şeklindeki öz-yeterlik inanışlarının matematik kaygısındaki rolünü incelediği çalışması ile benzerlik göstermektedir. Çünkü Hoffman (2010) bu çalışmasında düşük öz-yeterlik ile yüksek matematik kaygısı arasındaki ilişkiyi ortaya koymuştur. Kaygıya sebep olan başka bir etmen her zaman gerekli olma, matematiğe her an ihtiyaç duyulabilmesinden kaynaklı bir kaygı oluşması sonucunda ortaya çıkmış olup; ihtiyaç arttıkça kaygının artabileceği şeklinde yorumlanabilir. Dersi alan ve almayan grupta kaygım yok diyen katılımcıların oranı (\%15; \% 18) oldukça düşüktür. Bu durumda matematik kaygısının yüksek olduğunun başka bir göstergesidir. Sırmacı (2007) tarafından üniversite öğrencilerinin kaygılarının incelendiği bir 
çalışmada da sözel bölümlerdeki öğretmen adaylarının (sosyal bilgiler, tarih, coğrafya) kaygı düzeylerinin diğer bölümlere göre daha yüksek olduğu tespit edilmiştir.

Dördüncü sorunun bulguları incelendiğinde matematiği seçmeli ders olarak alan katılımcıların \% 92'si almayanların ise \% 76'sı keşke matematik bilseydim şeklinde bir düşünceye sahiptir. Her iki oranında oldukça yüksek olmasına rağmen dersi almayan grupta bu oranın daha da düşük olmasının altında yatan sebepler oldukça farklılaşabilir. Var kategorisinde yer alan ve aynı zamanda bu dersi almayan katılımcıların cevapları bütün sorular bazında incelendiğinde bu grubun matematiği bilen-yapan, matematik kaygısı-fobisi olmayan ya da matematiği hiç bilmeyen-hiç yapamayan, matematik kaygısı-fobisi olan birbirine zıt özelliklerin oluşturduğu bir grup olarak karşımıza çıktığı görülmektedir. Ayrıca dersi alan ve almayan her iki grupta da \%75' lik bir uyuşma ile aynı kodların ortaya çıkması oldukça dikkat çekicidir. Katılımcılar aynı sebeplerden dolayı matematik bilmek istemelerine rağmen ders seçimleri farklılaşmıştır. Burada da yine kaygı, fobi, öğrenilmiş çaresizlik gibi durumların ders seçiminde devreye girerek engelleyici bir faktör oluşturduğu düşünülebilir. Bunlara ek olarak katılımcıların belirtmiş oldukları ifadeler sonucu oluşan günlük yaşamdaki gereklilik, kariyer kaygısı, farklılık katması ve kendini ispatlama kodları matematik bilme isteklerinin birer sebebi olarak ortaya çıkmıştır.

Beşinci sorunun bulguları incelendiğinde algılanan matematiğin yararlılı̆̆ı bütün katılımcılar tarafından kabul edilmiştir denilebilir. Çünkü kategoriler evet ve kısmen şeklinde oluşmuş olup; matematik dersini alan grupta evet kategorisi \% 92, kısmen kategorisi ise \% 8; dersi alamayan grupta ise evet kategorisi \% 53 kısmen kategorisi ise \% 47 ile meydana gelmiştir. Dersi alan ve almayan katılımcıların evet kategorisini oluşturan kodları \%100 oranında benzerlik göstermektedir. Tablo 4’te keşke matematiği bilseydim şeklinde bir düşüncesi olmayan A-3 ve B-6 kodlu öğrencilerin Tablo 5'te evet kategorisinin hayatı kolaylaştırma kodunda yer aldığı görülmektedir. Yine bu şekilde bir düşünceye sahip olan B-7 k1smen kategorisinin hayatı kolaylaştırma kodunda, B-5 ve B-8 ise sebep yok odunda yer almaktadırlar. Dolayısıyla bu 5 katılımcı matematiği bilseydim diye düşünmemekle beraber algıladıkları matematiğin kısmen veya evet seviyesinde faydası olduğunu düşünmektedirler. Beşinci sorudaki evet kategorisinde en dikkat çeken nokta matematiğin hayatı kolaylaştırman fonksiyonuna \% 67' lik bir oranla vurgu yapılmasıdır. B-2: “Evet matematiğin günlük hayatımızı kolaylaştırdığını düşünüyorum. Çünkü marketten üç tane ekmek alırken bile basitte olsa bir matematiksel işlem gerekiyor” örneğinde olduğu gibi hesap kitap kodunun da günlük 
hayatı kolaylaştırıcı rolü düşünüldüğünde hayatı kolaylaştırma matematiğin algılanan faydasının en büyük ve tek etkeni olarak karşımıza çıkmaktadır.

Altıncı sorunun bulguları incelendiğinde dersi almayan katılımcıların dahi dersin sosyal bilgiler lisans programında \% 70'lik bir oranla yer alması gerektiğini düşünmeleri çarpıcı bir sonuç olarak göze çarpmaktadır. İki grup arasındaki fark ise dersi alan grubun \% 75 oranı ile dersi almayan grubun ise $\% 17$ oranı ile matematik dersinin sosyal bilgiler lisans programında her dönem olması gerektiğini düşünmesidir. Öğretim programa matematik dersinin eklenmesinin öğretmen adaylarının matematiğin doğasına, öğrenimine ve öğretimine yönelik inanışları üzerinde etkisi olacağı bir gerçektir.

Bütün bu sonuçlar 1şığında söylenebilir ki sosyal bilgiler lisans programı öğrencileri algılanan matematik başarıları düşükte olsa kaygıları da olsa fobileri de olsa bir şekilde matematiğin bütün kapıları açacak sihirli bir anahtar olduğunu düşünmektedir. Yani yapamasalar da matematiği yapmak, bilmeseler de matematiği öğrenmek istemektedirler ve matematiğin günlük hayattaki ve kariyer hedeflerindeki işlevleri hakkında bir farkındalığa sahiplerdir. Bu istekler ve farkındalık da katılımcıların ifadelerinden anlaşıldığı üzere atanmak için girmek zorunda oldukları KPSS'nin büyük bir etkisi vardır. Bu nedenle atanmaları için KPSS'nin bir ön koşul olduğu ve aynı zamanda matematik yapmak zorunda oldukları sürece sosyal bilgiler lisans programında da matematik dersinin yer alması özellikle de motive edici bir unsur olması açısından son sınıfta veya her dönem seçmeli ders olarak yer alması önem arz etmektedir. 


\section{Kaynakça}

Araujo, J., L. (2008). Contradictions in mathematical modeling activities from a critical mathematics education perspective. J.F. Matos, P. Valero \& K. Yasukawa (Ed). Proceedings of the Fifth International Mathematics Education and Society Conference içinde. Lisbon: Centro de Investigação em Educação, Universidade de Lisboa Department of Education, Learning and Philosophy, Aalborg University, 177- 185. 14.06.2012tarihindehttp://www.researchgate.net/profile/ Alan_Bishop4/publication/ 44828702_Mathematics_education_and_society/links/549a5a240cf2b8037135936e.pd $\mathrm{f \# page=185}$ adresinden elde edildi.

Arıkan, G. (2004). Kırşehir ilköğretim II. kademe öğrencilerinin matematik kaygı düzeyleri ile matematik başarıları arasındaki ilişki. (Yayınlanmamış yüksek lisans tezi). Gazi Üniversitesi Eğitim Bilimleri Enstitüsü. Ankara

Aydın, B. (2011). İlköğretim ikinci kademe düzeyinde matematik kaygısının cinsiyete göre farklılıkları üzerine bir çalışma. Kastamonu Eğitim Dergisi, 19(3), 1029-1036.

Başar, M., Ünal, M. ve Yalçın, M. (2002, Eylül). İlköğretim kademesinde başlayan matematik korkusunun nedenleri. V. Ulusal Fen Bilimleri ve Matematik Eğitimi Kongresinde sunulan bildiri, Orta Doğu Teknik Üniversitesi, Ankara.

Bekdemir, M. (2007). İlköğretim matematik öğretmen adaylarındaki matematik kaygısının nedenleri ve azaltılması için öneriler (Erzincan Eğitim Fakültesi örneği). Erzincan Ĕ̈itim Fakültesi Dergisi, 9(2), 131-144.

Bekdemir, M., Işık, A. ve Çıkılı, Y. (2004). Matematik kaygısını oluşturan ve artıran öğretmen davranışları ve çözüm yolları. Eurasian Journal of Educational Research, 16, 88-94.

Berberoğlu, G. (2007). Türk bakış açısından PISA araştırma sonuçları. 11.06. 2012 tarihinde http://www.konrad.org.tr/Egitimturk/07girayberberoglu.pdf. adresinden elde edildi.

Bindak, R. (2005). İlköğretim öğrencileri için matematik kaygı ölçeği. Fırat Üniversitesi Fen ve Mühendislik Bilimleri Dergisi, 17(2), 442-448.

Büyüköztürk, Ş., Çakmak, E. K., Akgün, Ö. E., Karadeniz, Ş. ve Demirel, F. (2011). Bilimsel araştırma yöntemleri (10. Bask1). Ankara: Pegem Akademi.

Byrd, P. (1982) A descriptive study of mathematics anxiety: its nature and antecedents. (Unpublished doctoral thesis). Indiana University. http://search.proquest.com/pqdtglobal/docview/303215078/fulltextPDF/38247D93138 5490BPQ/2?accountid=11054

Dede, Y. ve Karakuş, F. (2012, Haziran). Matematik öğretmen adaylarının matematiğe yönelik inançları üzerinde ögretmen ĕgitimi programlarının etkisi. X. Ulusal Fen Bilimleri ve Matematik Eğitimi Kongresi'nde sunulan bildiri. Niğde Üniversitesi, Niğde.

Duatepe, A. ve Çilesiz, Ş. (1999). Matematik tutum ölçeği geliştirilmesi. Hacettepe Üniversitesi Eğitim Fakültesi Dergisi, 16(17), 45-52.

Dursun, Ş. ve Dede, Y. (2004). Öğrencilerin matematikte başarısını etkileyen faktörler: matematik öğretmenlerinin görüşleri bakımından. Gazi Eğitim Fakültesi Dergisi, 24(2), 217-230.

Duru, A. (2002). Van ilindeki lise birinci sınıflarda cinsiyet farklılı̆̆ının matematik başarısı üzerindeki etkisinin araştırılması. (Yayınlanmamış yüksek lisans tezi). Yüzüncü Yı1 Üniversitesi Fen Bilimleri Enstitüsü, Van.

Duru, A., Akgün, L. ve Özdemir, M. E. (2005). İlköğretim öğretmen adaylarının matematiğe yönelik tutumlarının incelenmesi. Atatürk Üniversitesi Kazım Karabekir Ĕ̈itim Fakültesi Dergisi, 11, 520-536. 
Erözkan, A. (2004). Üniversite öğrencilerinin sınav kaygısı ve başa çıkma davranışları. Muğla Üniversitesi SBE Dergisi, 12, 13-38.

Frary, R. B. ve Ling, J. L. (1983). A factor-analytic study of mathematics anxiety. Educational and Psychological Measurement, 43, 985-993.

Gündoğdu, H. M. (1994). The relationship between helpless explanatory style, test anxiety and academic achievement among sixth grade basic education students. (Yayınlanmamış yüksek lisans tezi). Orta Doğu Teknik Üniversitesi, Ankara.

Hannula, M. (2005, Ağustos). Affect in mathematical thinking and learning. The Future of Mathematics Education and Mathematics Learning. BIFEB Strobl, Austria.

Hembree, R. (1988). Correlates, causes, effects, and treatment of test anxiety. Review of Educational Research, 58, 47-77.

Hergenhahne B. R. (1988). An introduction to theories of learning (3th ed.). Newyork: Macmillan.

Hoffman, B. (2010). "I think I can, but I'm afraid to try": The role of self-efficacy beliefs and mathematics anxiety in mathematics problem-solving efficiency. Learning and Individual Differences, 20, 276-283.

Jackson, C. D. ve Leffingwell, R. J. (1999). The role of instructors in creating mathematics anxiety in students from kindergarten through college. Mathematics Teacher, 92(7), 583-586.

Kahramaner, Y. ve Kahramaner, R. (2002). Üniversite eğitiminde matematik düşüncenin önemi. İstanbul Ticaret Üniversitesi Dergisi, 1(2), 15-25.

Keçeci, T. (2011, Nisan). Matematik kaygısı ve korkusu ile mücadele yolları. 2nd International Conference on New Trends in Education and Their Implications kongresinde sunulan bildiri. Akdeniz Üniversitesi, Antalya.

McMillan, J. H. ve Schumacher, S. (2006). Research in education evidence-based inquiry (6th ed.). Boston: Pearson Education.

Miller, L. D. ve Mitchell, C. E. (1994). Mathematics anxiety and alternative methods of evaluation. Journal of Instructional Psychology, 21(4), 353-358.

Özgüven, İ. E. (1994). Psikolojik testler. Ankara: PDREM Yayınları.

Pajares, M. F. (1992). Teachers' beliefs and educational research: Cleaning up a messy construct. Review of Educational Research, 62(3), 307-332.

Reglin, G.L. (1990). The effects of individualized and cooperative computer assisted instruction on mathematics achievement and mathematics anxiety for prospective teachers. Journal of Research on Computing in Education, 22(2), 404-414.

Richardson, F. C. ve Suinn, R. M. (1972). The mathematics anxiety rating scale: Psychometric data. Journal of Counseling Psychology, 19, 551-554.

Savaş, E., Taş, S. ve Duru, A. (2010). Matematikte öğrenci başarısını etkileyen faktörler. İönü Universitesi Eğitim Fakültesi Dergisi, 11(1), 113-132.

Seipp, B. (1991). Anxiety and academic performance: A meta-analysis of findings. Anxiety Research, 4, 27-41.

Senemoğlu, N. (2011). Gelişim, öğrenme ve öğretim: Kuramdan uygulamaya (20. Baskı). Ankara: Pegem A Yayıncılık.

Sırmacı, N. (2007). Üniversite öğrencilerinin matematiğe karşı kaygı ve tutumlarının incelenmesi: Erzurum örneklemi. Eğitim ve Bilim, 32(145), 53-70.

Şahan, G. (2006). Matematik korkusunda öğretmenin rolü. Eğitim Bilimleri Kongresi: 1315 Eylül 2006. Muğla Üniversitesi.

Şahin, Y. F. (2004). Ortaöğretim öğrencilerinin ve üniversite öğrencilerinin matematik korku düzeyleri. Eğitim Bilimleri ve Uygulama Dergisi, 3(5), 53-74. 
Townsend, M. A. R., Moore, D. W., Tuck, B. F. ve Wilton, K. M. (1998). Self concept and anxiety in university students studying social science statistics within a co-operative learning structure. Educational Pschology, 18(1), 41-55.

Tunç, M. P. ve Haser, Ç. (2012, Haziran). Sınıf öğretmeni adaylarının matematik öğretimine ilişkin inanışlarının incelenmesi. X. Ulusal Fen Bilimleri ve Matematik Eğitimi Kongresi’nde sunulan bildiri. Niğde Üniversitesi, Niğde.

Yenilmez, K. ve Duman, A. (2008). İlköğretimde öğrenci başarısını etkileyen faktörlere ilişkin öğrenci görüşleri. Sosyal Bilimler Dergisi, 19, 251-268.

Yıldırım, A. ve Şimşek, H., 2006. Sosyal bilimlerde nitel araştırma yöntemleri (6. Baskı). Ankara: Seçkin Yayıncılık. 